\title{
Serum albumin level in an urban Nigerian population
}

\author{
BY H. O. ADEWOYE AND J. F. FAWIBE \\ Department of Clinical Pathology, College of Medicine, University of Lagos, \\ Private Mail Bag 12003, Lagos, Nigeria \\ (Received 6 January 1978 - Accepted I9 April 1978)
}

\begin{abstract}
I. Serum albumin levels have been estimated in healthy adult Nigerians. The average level of albumin was $41.4 \mathrm{~g} / \mathrm{l}$ and there was no sex difference, but the findings differed from that of a previous survey in Ibadan. The importance of serum albumin measurement in relation to the socio-economic and dietary habits of the population has been reviewed.

2. It is concluded that socio-economic, dietary and cultural changes associated with Western education could be responsible for the increased level of serum albumin in this healthy population.

3. It is suggested that similar surveys should be done by locally-practising chemical pathologists.
\end{abstract}

The measurement of serum albumin is one of the most important routine determinations in a clinical biochemistry laboratory.

Serum albumin levels in Nigerians have been found to be lower than reference values quoted in standard texts (Edozien, 1957).

This has been accounted for by difference in dietary habits often due to a lower standard of living and to genetic factors (Edozien, 1957; Edozien, Morley \& Boyo, 1960).

Over the years, with the increase in standard of living due to improved 'earning power' and public education, dietary habits have changed and the level of serum albumin would be expected to change.

It was considered necessary to establish a normal range of serum albumin for the local healthy population covered by the Lagos University Teaching Hospital laboratories.

\section{MATERIALS AND METHODS}

Serum albumin level was determined in 4I5 healthy male and female subjects resident in Lagos.

The population sample consisted of male and female volunteers of the low-income group working in industrial factories at Ikeja.

The age range was from 18 to 30 years, and the samples were collected in May, June and July 1976 .

A sample $(6 \mathrm{ml})$ of blood was withdrawn from the ante-cubital vein of each subject between 09.00 hours and 10.00 hours, into a dry 'non-anticoagulate' glass bottle.

Albumin determination was made on each serum sample by the method of Bartholomew \& Delaney (1964, I966).

To $4 \mathrm{ml}$ buffered indicator bromocresol green, $\mathrm{pH} \mathrm{3.8,} \mathrm{were} \mathrm{added} 0.02 \mathrm{ml}$ serum, and after mixing, the extinction at $637 \mathrm{~nm}$ was determined with buffered indicator as the blank, using a spectrophotometer (SP 600 series 2 ; Pye-Unicam, Cambridge, UK).

A protein standard containing I g protein-nitrogen/l (Armour Pharmaceutical Company, Chicago, Illinois 60690 , USA) was used to prepare a standard curve. Total protein was determined by the Biuret method of Reinhold (1953) using the Biuret reagent of Gornall, Bardawill \& David (1949) and King (I95I).

Total globulin is obtained by subtracting the albumin value from the total protein value obtained on the same sample of serum. 
Table 1 . Serum albumin values $(g / l)$ for healthy adult urban Nigerians*

$\begin{array}{ccccc}\text { No. of subjects } & \text { Sex } & \text { Mean } & \text { sD } & \text { Mean } \pm 2 \text { SD } \\ 230 & \circ & 40 \cdot 9 & 4 \cdot 3 & 32 \cdot 3-49 \cdot 5 \\ 185 & + & 4 I \cdot 9 & 5 \cdot 0 & 31 \cdot 9-51 \cdot 9 \\ \text { Total 4I5 } & - & 41 \cdot 4 & 5 \cdot 2 & 3 \times \cdot 0-51 \cdot 8\end{array}$

* For details, see p. 439 .

RESULTS

The results of serum albumin determinations in the subjects studied are summarized in Table I.

The mean value for the total population was $4 \mathrm{I} \cdot 4 \mathrm{~g} / \mathrm{l}$. The mean value for the female population was $4 \mathrm{I} \cdot 9 \mathrm{~g} / 1$ and this was higher than the mean value of $40.9 \mathrm{~g} / \mathrm{l}$ for the male population but the difference was not statistically significant $(P>0.05)$.

Total protein and total globulin values $(g / 1)$ were: mean value for total protein $76 \cdot 7$, mean value for total globulin $32 \cdot 7$, total globulin (mean $\pm 2 \mathrm{SD}$ ) $23 \cdot 0-43 \cdot 0$, total protein (mean \pm 2 SD) $65 \cdot 5-87.9$.

\section{DISCUSSION}

The plasma albumin level is usually requested at the same time as total protein, but generally measurement of albumin in plasma (serum) is found to be of much greater diagnostic value than determination of total protein. The albumin:globulin value is of no physiological significance.

Albumin is the protein mainly responsible for maintenance of colloid osmotic pressure. In addition it acts as a specific transport mechanism for a number of substances, including fatty acids, urate, calcium, bilirubin and various drugs.

Albumin is synthesized in the liver parenchymal cells, and this may be affected in both acute and chronic liver disease, in malnutrition and malabsorption. Thus, measurement of plasma albumin is particularly valuable as an index of severity in chronic liver disease, protein-energy malnutrition, nephrotic syndrome and exudative enteropathy.

Albumin can be estimated by a variety of methods, each depending on a different property of the protein. Different values may be obtained using the same specimen, depending on the methods of estimation used, and so the normal range for every laboratory should be determined. Furthermore, size, ability and technical expertize make it difficult to isolate proteins in the pure form for assay routinely and yet achieve the same precision and specificity as for simpler compounds.

The various techniques that have been used for albumin estimation include immunological methods, with the great advantage of specificity, and methods which are based on biological properties of protein. Albumin can be separated from other proteins by chemical techniques (e.g. salt fractionation) or by electrophysical techniques (e.g. cellulose-acetate electrophoresis). It can also be determined directly using spectrophotometry or by measuring intensity of colour produced when bound to a dye, e.g. bromocresol green, using a spectrophotometer. The dye-binding technique is easier for routine estimation and its advantages have been listed by the (British) Association of Clinical Biochemists (Scientific and Technical Committee) 1967. This is the routine method used in the Chemical Pathology Laboratories of Lagos University Teaching Hospital. The technique is reproducible, accurate, easy and reasonably fast when there are large numbers of samples.

The importance of serum albumin estimation has been discussed previously, but in Nigeria its use in the biochemical assessment of state of nutrition (Arroyave, 1961) is of 
additional interest. The present study involved Nigerians of low-income group, and when compared to previous surveys the mean level of albumin was found to be higher than the mean level of $35.0 \mathrm{~g} / 1$ reported by Edozien (Edozien, 1957, 1958; Edozien et al. 1960).

Edozien et al. (1960) and Edozien (1965) found that the total serum protein levels of adult Nigerians were the same as those for adult Europeans, but that the albumin level was less (24-45 g/l). Referring to the finding of low albumin levels in other 'dark' races in which malnutrition is not prevalent because of the high standard of living, Edozien (1957, 1965) and Edozien et al. (1960) noted that the difference might be genetic.

The Biuret method for the estimation of total protein is the same as that used in the present study. Determination of albumin by the salt-fractionation techniques (Wolfson, Cohn, Calvary \& Ichiba, 1948; Gornall et al. 1949; Reinhold, 1953), as used by Edozien (1957), gives approximately the same results as the bromocresol green method in our experience, and that of other workers ( $r$ 0.93; Miyada, Baysinger, Notrica \& Nalcamuro, 1972), ( $r 0.987, P<0.00$ I ' with no significant difference between the two means'; (British) Association of Clinical Biochemists, 1967).

We found that the serum albumin levels were higher $(3 \mathrm{I} \cdot 0-5 \mathrm{I} \cdot 8 \mathrm{~g} / \mathrm{l})$ than those of Edozien (1957) $(26-40 \mathrm{~g} / \mathrm{l})$. The corresponding total protein level $(76 \cdot 7 \mathrm{~g} / \mathrm{l})$ was also higher than the value given by Edozien ( 1957$)(68 \mathrm{~g} / 1)$.

The total globulin value $(32 \cdot 7 \mathrm{~g} / \mathrm{l})$ was approximately the same as that of Edozien (1957) $(32 \mathrm{~g} / \mathrm{l})$. These differences cannot be explained on the basis of methodology. The high globulin levels still reflect the endemic infection in Nigeria. The serum albumin values were the same as adult European values (Edozien, I957; Horrobin \& Gunn, I970; Baron, 1974; Zilva \& Panall, 1975).

We consider therefore that dietary habits and an increase in the standard of living, and not genetic constitution, are responsible for the previous difference in serum albumin level.

\section{CONCLUSION}

It is considered that serum albumin determinations are of great diagnostic value in medical practice and therefore are routinely determined in our Chemical Pathology Laboratories using the value obtained in this study as the range of normal values for the healthy adult population in the Lagos area.

It is also considered that the increase in serum albumin value levels is due to improved dietary habits and a higher standard of living.

The authors thank Dr V. O. Awosika, Director, Estate Clinic Group, Kodesoh Street, Ikeja, Lagos, Nigeria, for allowing them to include Ikeja factory workers in this survey.

\section{REFERENCES}

Arroyave, G. (1961). Fedn Proc. Fedn Am. Socs exp. Biol. 20, 39.

Association of Clinical Biochemists (Scientific and Technical Committee) (1967). Tech. Bull no. II.

Baron, D. N. (1974). Short Textbook of Chemical Pathology, 3rd ed. London: English Universities Press.

Bartholomew, R. J. \& Delaney, A. M. (1964). Proc. Aust. Ass. Clin. Biochem. 1, 64.

Bartholomew, R. J. \& Delaney, A. M. (I966). Proc. Aust. Ass. Clin. Biochem I, 2 I4.

Edozien, J. C. (1957). J. clin. Path. ro, 276.

Edozien, J. C. (1958). W. Afr. med. J. 7, 121 .

Edozien, J. C. (1965). Jl W. Afr. Sci. Ass. ro, 23.

Edozien, J. C., Morley, D. C. \& Boyo, A. E. (1960). J. clin. Path. 13, 118.

Gornall, A. G., Bardawill, C. J. \& David, M. M. (I949). J. biol. Chem. 177, 75 I.

Horrobin, D. \& Gunn, A. (editors) (1970). In The International Handbook of Medical Science, p. 698. London: Medical and Technical Publishing Co. Ltd. 
King, E. J. (195I). In Recent Advances in Clinical Pathology, 2nd ed. [S. C. Dyke, editor]. London: J. \& A. Churchill.

Miyada, S., Baysinger, V., Notrica, S. \& Nalcamuro, R. M. (1972). Clin. Chem. r8, 52.

Reinhold, J. G. (1953). Standard Methods of Clinical Chemistry, vol, I, p. 88. [M. Reinder, editor]. New York: Academic Press.

Wolfson, W. Q., Cohn, C., Calvary, E. \& Ichiba, F. (1948). Am. J. clin. Path. r8, 723.

Zilva, J. F. \& Panall, P. R. (1975). Clinical Chemistry in Diagnosis and Treatment, 2nd ed. Lloyd-Luke. 